Anusha Devi Ramessur, John H. Bothwell, Christine A. Maggs, Sook Yee Gan and Siew Moi Phang*

\title{
Agrobacterium-mediated gene delivery and transient expression in the red macroalga Chondrus crispus
}

https://doi.org/10.1515/bot-2018-0028

Received 11 March, 2018; accepted 13 July, 2018; online first 12 September, 2018

\begin{abstract}
Molecular resources and transgenic studies in red algae are lagging behind those for green algae. The Agrobacterium-mediated gene-transfer method routinely used in plant transformation has not been fully utilised in the red algae, which, as an important source of phycocolloids, warrant more studies. In this regard, a stepwise methodology was developed for Agrobacterium-mediated transformation of the carrageenophyte Chondrus crispus using pCAMBIA 1301 and a construct featuring a codonoptimized beta-glucuronidase (GUS) reporter gene driven by the endogenous Chondrus actin promoter. The effects of several factors on transformation efficiency were investigated. An intimate association of Chondrus and bacterial cells was observed using scanning electron microscopy. GUS transient expression within Chondrus cortical and medullary cells with both expression cassettes testified to the amenability of Chondrus to Agrobacterium-mediated transformation. Darker staining, indicative of higher GUS activity, was observed with the Chondrus-specific construct, suggesting its superiority over the pCAMBIA 1301. Presence of acetosyringone, the wounding method and the type of co-cultivation medium significantly affected the transformation outcome and efficiency. The Agrobacterium-mediated transient expression presented here
\end{abstract}

\footnotetext{
*Corresponding author: Siew Moi Phang, Institute of Ocean and Earth Sciences, University of Malaya, 50603 Kuala Lumpur, Malaysia, e-mail: phang@um.edu.my

Anusha Devi Ramessur: School of Biological Sciences, Medical Biology Centre, Queen's University Belfast, Belfast, Northern Ireland John H. Bothwell: School of Biological Sciences, Medical Biology Centre, Queen's University Belfast, Belfast, Northern Ireland; and School of Biological and Biomedical Sciences, Durham University, South Road, Durham, England

Christine A. Maggs: School of Biological Sciences, Portaferry Marine Laboratory, Queen's University Belfast, Belfast, Northern Ireland Sook Yee Gan: Department of Life Sciences, School of Pharmacy, International Medical University, No. 126, Jalan Jalil Perkasa 19, Bukit Jalil, 57000 Kuala Lumpur, Malaysia
}

constitutes a first step towards tailoring a transformation strategy for Chondrus, which can serve to facilitate further transgenic studies in this important red alga.

Keywords: algal biotechnology; gene engineering; genetic transformation; transformed algae; transgenic algae.

\section{Introduction}

The red macroalga, Chondrus crispus Stackhouse, found along the rocky shores of the North Western and North Eastern Atlantic, is an important commercial source of the phycocolloid carrageenan, which is used as a gelling, thickening and stabilizing agent in the food, cosmetic and phamaceutical industries (Guiseley 1989, Necas and Bartosikova 2013). According to the Food and Agricultural Organisation, 2000 tonnes of Chondrus were harvested in the year 2005. Chondrus was historically the only source of carrageenan and contributed to the approximately US\$417 million per annum carrageenan market (Kraan 2012), highlighting its importance.

The greatest diversity in algae can be observed within the red algae or Rhodophyta (Yoon et al. 2004, Maggs et al. 2008, Verbruggen et al. 2010), many of which have not yet been adequately studied. The red algae deserve more attention for their potential - by virtue of their unique biosynthetic pathways, cell wall components and unique pigments absent in land plants (Collén et al. 2013, Brawley et al. 2017). They are a mine of novel bioactive compounds (Holdt and Kraan 2011) that can be harnessed by the biotechnological industry. Studying the red algae, an ancient eukaryote lineage and a potential sister group to green algae, can additionally increase our understanding of the evolution of other algae and land plants (Collén et al. 2013).

In order to tap into the above-mentioned economic potential of the red macroalgae, a molecular toolkit for red algae is desirable, but lacking. It is crucial to develop reliable transgene delivery techniques for analysing the expression, function and regulation of red algal endogenous genes which will, in time, allow the engineering of economically important traits in algae such as 
phycocolloid quality and yield. Currently, several species of red algae have been transformed: the unicellular Cyanidioschyzon merolae (Minoda et al. 2004) and Porphyridium sp. (Lapidot et al. 2002), and the macroalgae Pyropia yezoensis (Mizukami et al. 2004, Hirata et al. 2014), Pyropia miniata (Kübler et al. 1994), Pyropia tenera (Son et al. 2011), Pyropia leucosticta (Lin et al. 2004), Porphyra haitanensis (Wang et al. 2010), Kappaphycus alvarezii (Kurtzman and Cheney 1991), Gracilaria changii (Gan et al. 2003) and Gracilaria gracilis (Huddy et al. 2012). So far, algal transgenic research has heavily focused on microalgae, hence more studies on macroalgae are warranted.

For transformation in macroalgal systems, methods based on temporary cell membrane permeabilization e.g. electroporation and biolistics are mostly used (Gan and Maggs 2017). There are limited reports on the use of crown gall-causing Agrobacterium to transform macroalgae: Pyropia yezoensis (Cheney et al. 2001), Gracilaria changii (Gan et al. 2005) and Kappaphycus alvarezii (Handayani et al. 2014, Triana et al. 2016). Several microalgae such as Chlamydomonas reinhardtii (Kumar et al. 2004, Pratheesh et al. 2014), Chlorella vulgaris (Cha et al. 2012), Haematococcus pluvialis (Kathiresan et al. 2009), Nannochloropsis sp. (Cha et al. 2011), Schizochytrium (Cheng et al. 2012), Dunaliella bardawil (Anila et al. 2011) and Dunaliella salina (Srinivasan and Gothandam 2016) have been transformed with Agrobacterium. Agrobacterium is routinely used in plant transformation because it allows heritable integration of genes, mostly in single copies and with little rearrangement in the host's genome (Gelvin 2003, Tzfira and Citovsky 2006, Bourras et al. 2015, Hwang et al. 2015, 2017). The basic mechanism used by the bacterium has long been known: phenolic exudates released from injured plant tissue attract the bacteria, which move to the tissue by chemotaxis, attach to it and infect the wounded tissue via the transfer of a segment of the Ti plasmid into the cells (Simoh et al. 2007, Bhattacharya et al. 2010, Subramoni et al. 2014). Once inside the cell, the T-DNA will translocate to the nucleus and integrate into the host genome (Zupan et al. 2000, Tzfira and Citovsky 2002, Bourras et al. 2015, Hwang et al. 2017). This infection is mediated by the collective action of virulence genes encoded by the bacterial chromosome (chv) and Ti-plasmid virulence (Vir) genes. With the aid of an exogenous supply of phenolics for virulence induction, the host range of Agrobacterium has successfully been expanded, under laboratory conditions, to yeast, fungi, human cells and sea urchins (Kunik et al. 2001, Bulgakov et al. 2006, Zheng et al. 2011, Zhang et al. 2014, Rolloos et al. 2015, Lin et al. 2017).
One way of improving transformation and gene expression efficiency in algae has been through the use of endogenous promoters of genes such as glyceraldehyde-3-phosphate dehydrogenase (GAPDH) (Fukuda et al. 2008), actin1 (Takahashi et al. 2010) and the heat shock protein HSP70 (Son et al. 2011). Proteins, especially those from species using non-canonical codes or containing regulatory elements which limit expression, are difficult to express in their non-native host since their codons might be rarely used in the host (Gustafsson et al. 2004). Hence, optimization of transgene codons to match the native host codon preference has resulted in improvements in transcription and translation efficiencies in various organisms including algae (Fukuda et al. 2008, Mikami et al. 2009, Kucho et al. 2013, Hirata et al. 2014, Šnajder et al. 2015, Barahimipour et al. 2016, Zhou et al. 2016).

The aim of this study was to develop and test a working Agrobacterium-mediated transformation protocol tailored to the complex red alga Chondrus crispus. The factors known to influence the efficiency of Agrobacterium-mediated transformation were investigated: (1) co-cultivation in induction medium or seawater (salinity 20), (2) inclusion $(100 \mu \mathrm{M})$ or exclusion of the phenolic acetosyringone during co-cultivation and (3) wounding using microparticle bombardment versus mechanical injury administered with a sharp, sterile sewing pin, and (4) using an endogenous Chondrus expression cassette. Chondrus crispus was considered a good candidate, being an economically valuable carrageenophyte with developed transcriptomic tools and a full genome sequence (Collén et al. 2013) which greatly facilitated adaptation of the expression cassette to Chondrus.

\section{Materials and methods}

\section{Algal collection, sterilization and culture}

Chondrus crispus female gametophytic fronds were collected from rock pools and the lower intertidal zone at various sites near Fanad Head, Co. Donegal, Ireland, and transported to Belfast for processing. Fronds were cut into about $4 \mathrm{~cm}$ segments and thoroughly washed with pasteurized seawater to remove associated debris. Epiphytic material and surface contaminants were brushed away under a stereomicroscope (Kyowa Optical SDZ-PL, Singapore). The thallus segments were surface-sterilized by immersion in $1.5 \%$ potassium iodide for $10 \mathrm{~min}$ followed by thorough rinsing in pasteurized seawater. They were cultured in seawater or one-tenth strength von 
Stosch medium (Guiry and Cunningham 1984; chemicals obtained from Sigma-Aldrich, UK) at $10^{\circ} \mathrm{C}$ under a $16: 8$ light/dark regime with aeration.

\section{Agrobacterium strains and binary vector constructs}

Agrobacterium strain LBA4404 was kindly provided by Andy Bailey, Bristol University, England. A Chondrus-specific GUS expression cassette was constructed (Figure 1A). The codons of a $1.812 \mathrm{kbp}$ bacterial GUS sequence from $\mathrm{pBI}$ 221 (GenBank accession AF502128.1) were modified manually by silent mutations to match the favoured codon usage of native Chondrus (Collén et al. 2013); this increased the G/C content of the GUS coding sequence from 52 to 66\% (Supplementary Figure S1). The $3.052 \mathrm{kbp}$ sequence upstream of the start codon of the Chondrus actin gene (CHC_T00008840001, NCBI Accession NW_005179192) on scaffold 307 (positions 29997-26946) was fused upstream of the Chondrus-specific GUS sequence while a $0.253 \mathrm{kbp}$ NOS terminator (GenBank accession AF502128.1) was fused downstream of the GUS sequence. This construct was cloned into the multiple cloning site of the 9.168 kbp binary vector, pRI 910 (Clontech). For Agrobacterium transformation, pRI 910 (Ac-GUS) and the binary vector pCAMBIA 1301 (Figure 1) were introduced separately into competent cells of the Agrobacterium strain LBA 4404 using the freeze/thaw method (Wise et al. 2006). For each expression cassette, two independent experiments, each with two replicates of 10 thalli, were conducted.

\section{Agrobacterium-mediated transformation of Chondrus}

In order to induce the bacteria for transformation, the virulence induction protocol outlined by Gelvin (2006) was followed with modifications. Agrobacterium was grown at $28^{\circ} \mathrm{C}$, with agitation at $225 \mathrm{rpm}$ overnight in $5 \mathrm{ml}$ Luria Bertani (LB) medium (10 $\mathrm{g} \mathrm{l}^{-1}$ tryptone, $5 \mathrm{~g} \mathrm{l}^{-1}$ yeast extract, $10 \mathrm{~g} \mathrm{l}^{-1}$ sodium chloride, $\mathrm{pH}$ 7; Merck, Germany) containing $50 \mu \mathrm{g} \mathrm{ml}^{-1}$ kanamycin (Sigma-Aldrich, UK). A volume of $500 \mu \mathrm{l}$ bacterial culture was diluted into $50 \mathrm{ml}$ Induction Medium (IM) [prepared using minimal medium as described by Ando et al. (2009) with addition of $0.5 \%$ (w/v) glycerol and $40 \mathrm{~mm}$ 2-( $N$-morpholino) ethanesulphonic acid (MES), pH 5.3] supplemented with kanamycin and rifampicin at $50 \mu \mathrm{g} \mathrm{ml}^{-1}$, and grown at $30^{\circ} \mathrm{C}$ for about $24 \mathrm{~h}$ until it reached an absorbance reading of $\mathrm{A}_{600 \mathrm{~nm}}=1.2$.

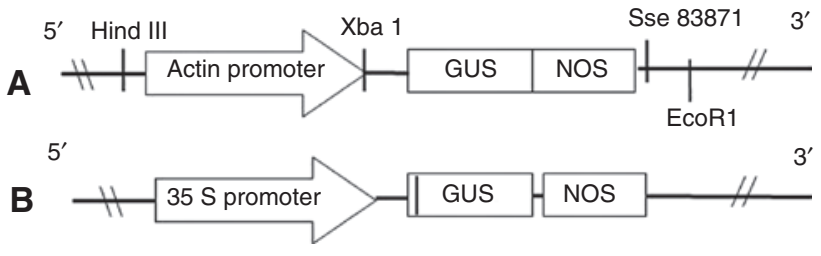

Figure 1: Features of binary vectors for Agrobacterium-mediated transformation.

(A) Chondrus-specific expression cassette. Salient features: $1.812 \mathrm{kbp}$ GUS gene modified to match the favoured codon usage of Chondrus, promoter region of the Chondrus actin gene, nopaline synthase (NOS) gene terminator from Genbank accession AF502128.1; (B) Binary vector pCAMBIA 1301. Salient features: GUS gene with castor bean catalase intron driven by a CAMV $35 \mathrm{~S}$ promoter and terminated by NOS.

The suspension was centrifuged for $15 \mathrm{~min}$ at $10,000 \mathrm{~g}$ to harvest the bacterial cells. The bacterial cells were resuspended in $100 \mathrm{ml}$ IM containing $100 \mu \mathrm{M}$ acetosyringone (Sigma-Aldrich, UK) and $50 \mu \mathrm{g} \mathrm{ml}^{-1}$ kanamycin and left to shake at $60 \mathrm{rpm}$ (to keep the bacteria suspended) for $24 \mathrm{~h}$ at $25^{\circ} \mathrm{C}$. The bacterial cells were pelleted by centrifugation and resuspended in IM or seawater (salinity 20) containing $100 \mu \mathrm{M}$ acetosyringone ready for co-cultivation with Chondrus thalli.

Immediately before co-cultivation with Agrobacterium, surface-sterilized thallus segments ( $1 \mathrm{~cm}$ in length) were desiccated for $15 \mathrm{~min}$, then pricks and tears were made on the surface using a pointed sterile pin. Biolistic wounding was achieved by bombarding gold microcarriers $(0.6 \mu \mathrm{m})$ at $1350 \mathrm{psi}$ into thalli using a PDS-1000/ He delivery system (Bio-Rad Laboratories, USA). Thallus segments were layered in the centre of a petri dish positioned in the middle of the target shelf at a distance of $3 \mathrm{~cm}$ from the microcarrier launch assembly. The bombardment chamber was evacuated to $63.5 \mathrm{~cm}$ of mercury and $500 \mu \mathrm{g}$ of uncoated gold microcarriers $(0.6 \mu \mathrm{m})$ was bombarded into the tissue with the biolistic machine.

Sterilized thallus segments, both wounded and unwounded (on glass slides in petri dishes), were co-cultivated with a suspension of Agrobacterium in seawater with $100 \mu \mathrm{M}$ acetosyringone. The dishes were incubated at room temperature $\left(18-20^{\circ} \mathrm{C}\right)$ for 2 days in the dark. Suitable controls were included: (1) Unwounded and untransformed thalli (thalli not subjected to Agrobacterium-mediated transformation), (2) Pin-pricked thalli co-cultivated with untransformed Agrobacterium LBA4404 bacteria, (3) Pin-pricked thalli cultivated without bacteria, and (4) Pin-pricked thalli co-cultivated with Agrobacterium bearing a construct where the GUS gene is absent (pRI 910 binary vector). 


\section{Developing a wash protocol for post-transformation}

To eliminate residual bacteria after transformation and avoid the occurrence of false GUS positives, a wash protocol was developed and cefotaxime (Sigma-Aldrich, UK) was tested for bacteriostatic effects on Agrobacterium. Two cefotaxime concentrations ( 500 and $800 \mathrm{mg} \mathrm{l}^{-1}$ ) were tested on thallus segments that had been co-cultivated with Agrobacterium LBA4404 cells. Every 2 days, the thallus segments were rinsed for $4 \mathrm{~min}$ with sterile seawater six times before incubation for $48 \mathrm{~h}$ in fresh seawater with replenished cefotaxime. A thallus segment was streaked on a LBA plate which was incubated at $28^{\circ} \mathrm{C}$ for up to 4 days to check for the persistence of Agrobacterium. This was conducted in triplicate.

\section{Post-transformation elimination of Agrobacterium}

Following co-cultivation, Agrobacterium cells were eliminated by brushing the surface of the thallus segments with an ethanol-sterilized paintbrush followed by rinsing in sterilized seawater. After three consecutive 4-min rinses in sterilized seawater, the transformed thalli were incubated with $500 \mathrm{mg} \mathrm{l}^{-1}$ cefotaxime for $48 \mathrm{~h}$ in the dark at $18^{\circ} \mathrm{C}$. A streak of the thallus was made on a LBA plate (which was then incubated for 2 days at $28^{\circ} \mathrm{C}$ and checked for the presence of bacteria). The previous step (rinsing and incubating in cefotaxime) was repeated every 2 days, adding fresh seawater with replenished cefotaxime until no bacterial colonies were obtained from the LBA streaking (within approximately 6 days). Antibiotic was washed away, and the tissue was transferred to enriched seawater at $18^{\circ} \mathrm{C}$ for recovery at a photoperiod of $16 \mathrm{~h}$ light: $8 \mathrm{~h}$ dark.

\section{Histochemical staining and microscopic analysis of thallus sections}

Histochemical staining of thallus segments was conducted after transformation (8 days following co-cultivation). These segments were washed several times in sterile seawater before incubating at $37^{\circ} \mathrm{C}$ for $2-3$ days in GUS staining solution made up in distilled water with $0.1 \mathrm{M} \mathrm{NaPO}_{4}$ at pH 7 (0.12 $\mathrm{M} \mathrm{Na}_{2} \mathrm{HPO}_{4}$ and $\left.0.08 \mathrm{M} \mathrm{NaH}_{2} \mathrm{PO}_{4}\right)$, $10 \mathrm{~mm}$ EDTA, $1 \mathrm{~mm} \mathrm{~K}_{3} \mathrm{Fe}(\mathrm{CN})_{6}$, 0.1\% Triton X-100 and $2 \mathrm{~mm}$ $\mathrm{X}$-gluc (5-bromo-4-chloro-3-indolyl- $\beta$-D-glucuronic acid). All chemicals were obtained from Sigma-Aldrich, UK.
Following the staining, chlorophyll was cleared by incubating the stained tissue for 2-3 days in $70 \%$ (v/v) ethanol after which sections made from the thalli were ready for viewing under the microscope.

Longitudinal and transverse sections through the cortical and medullary tissue of thalli were made using a sterile razor blade under a stereomicroscope to investigate the localization pattern of GUS expression within tissues. Sections were mounted on a slide in 50\% seawater: 50\% glycerol for viewing under a light microscope (Motic B series, USA) and photographed using an attached camera (Leica Microsystems, UK).

To view bacterial attachment to Chondrus thalli using scanning electron microscopy (SEM), thalli which had been co-cultivated with Agrobacterium (OD 1.2) for 2 days were first rinsed to wash away unattached bacteria, before being fixed. Fixation was carried out for $1 \mathrm{~h}$ at room temperature in $4 \%(\mathrm{w} / \mathrm{v})$ glutaraldehyde (Fisher Scientific, UK) in $0.1 \mathrm{M}$ sodium cacodylate buffer ( $\mathrm{pH} 7.4$ ) containing $3 \%$ $(\mathrm{w} / \mathrm{v})$ sucrose (Sigma-Aldrich, UK). The thalli were subsequently fixed in fresh fixative for a further $3 \mathrm{~h}$ at $4^{\circ} \mathrm{C}$, then washed overnight at $4^{\circ} \mathrm{C}$ in $0.1 \mathrm{M}$ sodium cacodylate buffer (pH 7.4) containing 3\% (w/v) sucrose. After post-fixation treatment in $1 \%$ osmium tetroxide (Sigma-Aldrich, UK) for $1 \mathrm{~h}$, the tissues were washed several times in fresh buffer, dehydrated using an ethanol series and dried in hexamethyldisilazane (Sigma-Aldrich, UK). The thalli were then mounted on aluminium stubs, sputter-coated with gold-palladium and viewed with a FEI Quanta 200 SEM operating at $10 \mathrm{kV}$.

\section{Statistical analysis}

The data were tested for normality using the KolmogorovSmirnov test. The Mann-Whitney non-parametric test was used to compare between two groups.

\section{Results}

\section{Agrobacterium LBA4404 cells successfully attached to Chondrus cells}

Under the SEM, short, rod-shaped bacterial cells about $0.8 \times 2 \mu \mathrm{m}$ were seen attached in large numbers (an estimated average of one bacterial cell per $\mu^{2}$ ) to the Chondrus thallus surface at the wound sites. Whole colonies were observed in a fibrillar mesh (Figure 2). 


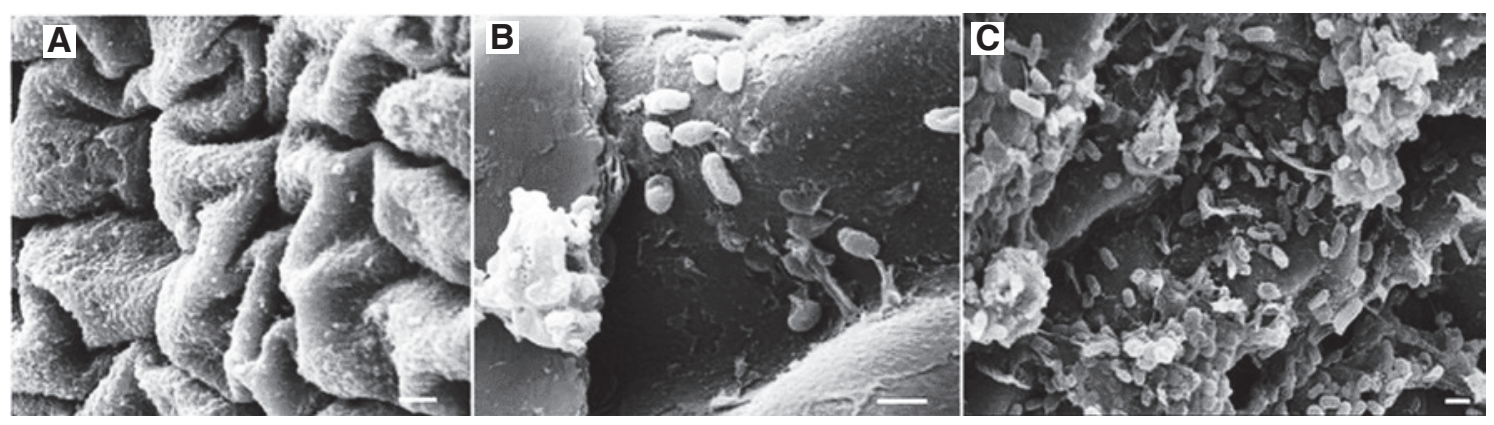

Figure 2: Intimate contact and adhesion of bacteria to wound sites of Chondrus thalli.

Thalli co-cultivated for $48 \mathrm{~h}$ in induction medium were fixed and viewed under a scanning electron microscope: (A) control thallus incubated without bacteria showing a clean bacterium-free surface; (B) close up view of rod-shaped bacteria attached to thallus surface at wound site; (C) bacterial film at wound sites on thallus surface.

\section{Protocol for eliminating Agrobacterium using cefotaxime}

The results of testing cefotaxime concentrations of 500 and $800 \mathrm{mg} \mathrm{l}^{-1}$ confirmed that this cefotaxime-supplemented wash protocol ensured that residual Agrobacterium and other culturable bacteria were eliminated on the thalli within 6 days (Table 1).

\section{Agrobacterium successfully delivered pCAMBIA 1301 into Chondrus thalli}

The methodology for transformation developed using pCAMBIA 1301 followed by the established wash protocol included controls to detect any false positives occurring

Table 1: Confirmation of the suitability of 500 and $800 \mathrm{mg} \mathrm{l}^{-1}$ cefotaxime in eliminating bacteria.

\begin{tabular}{lrrr}
\hline & & \multicolumn{2}{c}{ Mean number of colonies (per plate) } \\
\hline Day & \multicolumn{2}{c}{ Concentration of cefotaxime (mg l-1) } \\
\cline { 2 - 4 } & $\mathbf{0}$ & $\mathbf{5 0 0}$ & $\mathbf{8 0 0}$ \\
\hline 0 & $>1000$ & $>1000$ & $>1000$ \\
2 & $>300$ & $0.75 \pm 0.95$ & $1.25 \pm 0.95$ \\
4 & $>300$ & $0.25 \pm 1.60$ & $2.00 \pm 0.50$ \\
6 & $>300$ & 0 & $1.00 \pm 1.2$ \\
8 & $>300$ & 0 & 0 \\
\hline
\end{tabular}

Agrobacterium co-cultured with thalli was eliminated by consecutive washes and incubated in fresh antibiotic. Every 2 days, the thallus segments were rinsed for $4 \mathrm{~min}$ with sterile seawater six times before incubation for $48 \mathrm{~h}$ in fresh seawater with replenished cefotaxime. A thallus segment was streaked on a LBA plate which was incubated at $28^{\circ} \mathrm{C}$ for up to 4 days to check for the persistence of Agrobacterium. This was conducted in triplicates $(n=3)$. Colonies appearing from periodic streaks of thalli on LBA plates were counted. from indigenous activity of beta-glucoronidase in Chondrus (unwounded and untransformed thalli, Figure 3C), indigenous activity from LBA4404 bacterial cells (pinpricked thalli co-cultivated with untransformed Agrobacterium LBA4404 bacteria, Figure 3B), physiological response of algal cells to wounding (pin-pricked thalli cultivated without bacteria, Figure $3 \mathrm{~A}$ ) and vector components (pin-pricked thalli co-cultivated with Agrobacterium LBA4404 bearing a construct where the GUS gene is absent; pRI 910 binary vector, Figure 3D). None of these controls were stained. However, thalli transformed with pCAMBIA 1301 were stained blue (Figure 3E).

\section{Manipulating transformation conditions can enhance transformation efficiency}

As shown in Figure 4, among the pin-pricked thalli, a significant increase in transformation efficiency (higher percentage of thallus segments stained blue) was observed when seawater was used in preference to Induction Medium (Mann-Whitney test, $p=0.029$ ) in the presence of acetosyringone. However, no transformation was detected in the unwounded thallus segments or those wounded by bombardment when co-cultivation was conducted using seawater. In addition, without the presence of acetosyringone, transformation occurred at a significantly lower efficiency of less than 10\% (Mann-Whitney, $\mathrm{p}=0.004$ ).

\section{Successful expression obtained with the Chondrus-specific expression cassette}

Using the Agrobacterium transformation protocol developed using pCAMBIA 1301, the constructed pRI 910 (AcGUS) was delivered into thallus cells using seawater as 


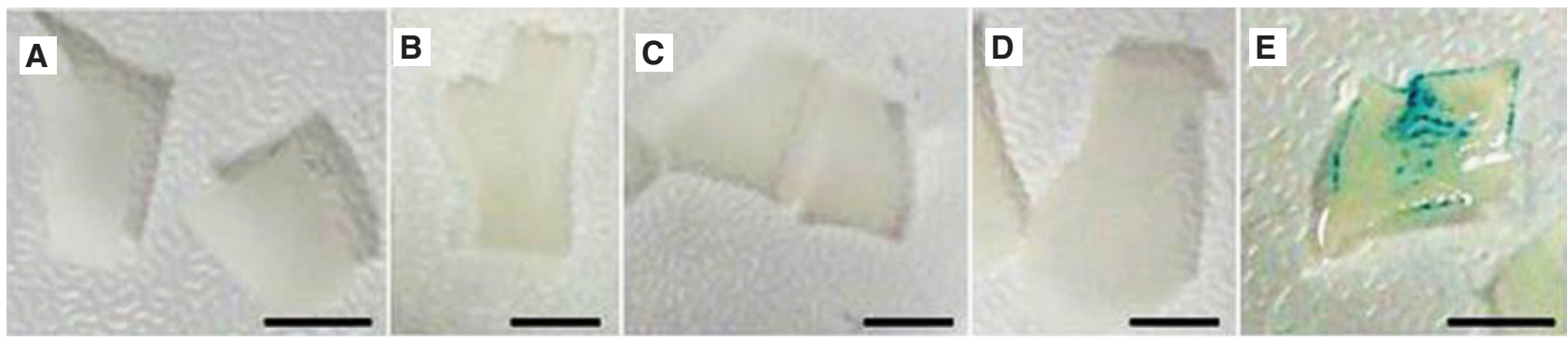

Figure 3: Histochemical staining and low-power microscopic analysis of Chondrus thallus segments for transient expression of GUS 7 days after co-cultivation.

(A) Pin-pricked thalli co-cultivated without bacteria, (B) pin-pricked thalli co-cultivated with untransformed LBA4404 bacteria, (C) unwounded and untransformed thalli, (D) pin-pricked thalli co-cultivated with LBA4404/pRI 910 (no GUS gene), (E) thalli transformed with LBA4404 (pCAMBIA 1301), scale bar: $1 \mathrm{~cm}$.

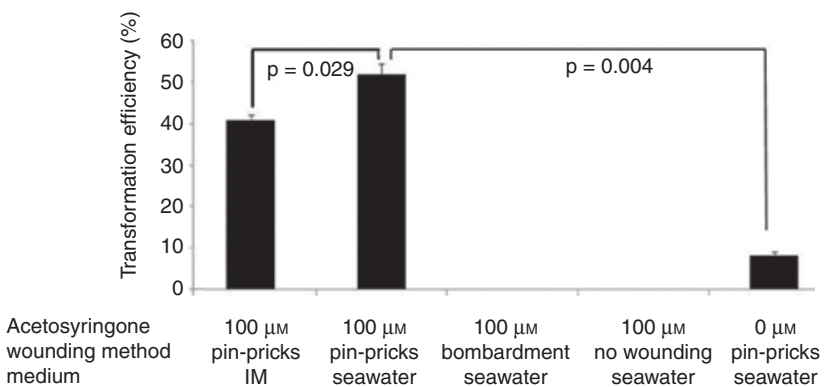

Figure 4: Effect of cultivation medium, wounding method and acetosyringone on Agrobacterium transformation efficiency. The transformation efficiencies of Chondrus thalli segments co-cultivated with pCAMBIA 1301-transformed Agrobacterium in seawater and Induction Medium (IM) were compared. Using seawater as co-cultivation medium, the wound-related treatments, namely biolistics wounding, wounding using pin-pricks and no wounding, were compared. The effect of acetosyringone $(100 \mu \mathrm{M})$ was also studied. Data are expressed as means $\pm S E(n=4)$. The Mann-Whitney non-parametric test was conducted to compare between two groups.

the co-cultivation medium and with the same controls as for pCAMBIA 1301. Blue colouration was apparent at the sites of tear, cut or wounding on Agrobacterium-mediated transformed thalli when compared to controls (Figure 5). Transverse sections through the tissue revealed blue localization of the GUS precipitate within the peripheral cortical cells and central medullary filaments. In general, a darker staining intensity was observed with pRI 910 (AcGUS). Furthermore, a higher transformation efficiency of $85 \%$ was obtained with this Chondrus-specific construct as opposed to 52\% with pCAMBIA 1301.

\section{Discussion}

In order to induce virulence in Agrobacterium and trigger the deployment of a Type IV secretion system (T4S) for
T-DNA delivery into the host, intimate contact between the bacterial cells and the host cells is essential (Matthysse and Wagner 1994, Gelvin 2003, Lacroix and Citovsky 2013, Heindl et al. 2014). Hence, the observed close association of the bacteria with the Chondrus thalli (Figure 2) constitutes a first line of evidence pointing to the amenability of the algal tissue to agro-infection.

Following Agrobacterium-mediated transformation with pCAMBIA 1301, successful T-DNA delivery and transient expression of the reporter GUS gene were evidenced by the clear visualization of the blue colour localized within Chondrus thallus cells (Figure 3E). This also pointed to the functionality of the Cauliflower Mosaic Virus 35S promoter in Chondrus which has also worked well in Dunaliella bardawil (Anila et al. 2011), Gracilaria changii (Gan et al. 2003), Kappaphycus alvarezii (Kurtzman and Cheney 1991) and Pyropia miniata (Kübler et al. 1994).

As observed with other red algae (Kübler et al. 1994, Kuang et al. 1998, Gan et al. 2003, Fukuda et al. 2008), the GUS reporter system unambiguously allowed the visualization of cellular GUS expression in Chondrus in the absence of endogenous beta-glucuronidase-like activity. In addition, to ensure that residual Agrobacterium and other culturable bacteria were eliminated after Agrobacterium-mediated transformation, cefotaxime was chosen for its wide spectrum of activity and low toxicity to eukaryotes (Mathias and Boyd 1986, Duan et al. 2013). No bacterial colonies were detected from the LBA streaking of thalli, which were subjected to the robust wash protocol using $500 \mathrm{mg} \mathrm{l}^{-1}$ cefotaxime after the Agrobacterium-mediated transformation (Table 1). Effective elimination of bacteria, together with the use of suitable transformation controls and the intron-containing GUS, helped to ensure the absence of false positives from endogenous GUS activity or non-target organisms.

The darker staining pattern of cells with pRI 910 (Ac-GUS) can be explained by a synergistic effect on the level of gene expression resulting from combining a 

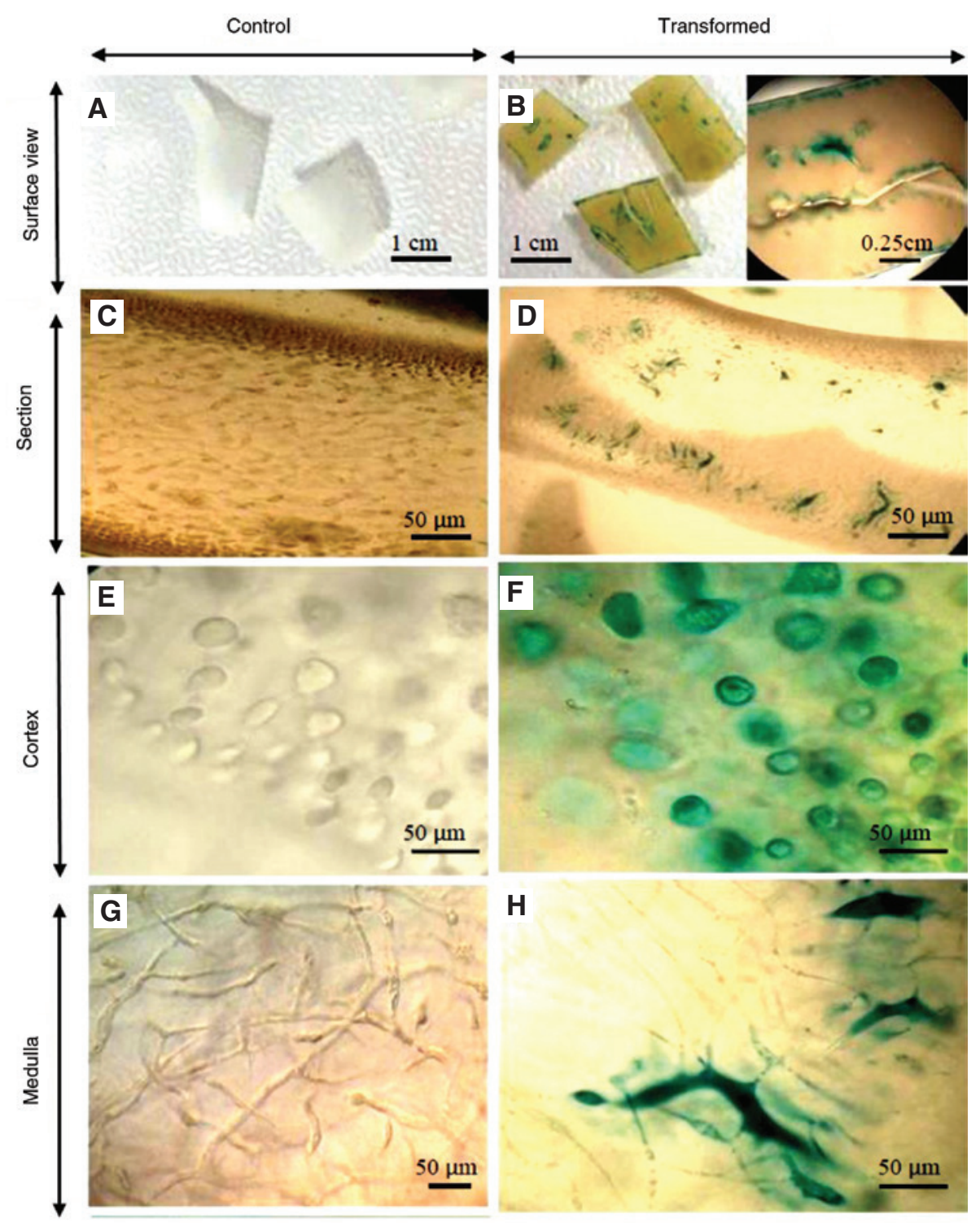

Figure 5: GUS expression in Chondrus thallus segments transformed with LBA 4404/pRI 910 (Ac-GUS).

(A) Surface view of control thallus not co-cultivated with Agrobacterium, (B) surface view of transformed thallus showing GUS expression at wound sites, (C) section through untransformed thallus, (D) thallus section within wounded area showing blue medullary cells at wound spots, (E) cortical cells from untransformed control thallus, (F) GUS-expressing cortical cells in transformed thallus, (G) medullary filaments from untransformed control thallus, $(\mathrm{H})$ medullary filaments from transformed thallus.

strong native promoter with a codon-optimized reporter gene. This effect has also been reported by Fukuda et al. (2008). Although it was not possible in this study to tease out the separate effects of the actin promoter or the GUS gene on the level of gene expression, interesting interpretations can still be made. Adjusting the codon usage to that favoured by Chondrus, in conjunction with using its endogenous actin promoter, seemed to have enhanced recognition by the molecular machinery of Chondrus. Successful transcription of the Chondrus-tailored GUS gene indicated that the constitutive actin promoter together with any necessary upstream elements were contained within the $3 \mathrm{kbp}$ sequence upstream of the Chondrus actin start codon. These same observations were also made by Takahashi et al. (2010) who isolated a $3.1 \mathrm{kbp}$ region encompassing the promoter of the actin1 gene in Pyropia yezoensis. This housekeeping gene, expected to be functional in all tissues at all times as an essential component of the cell cytoskeleton (Seagull 1989), proved to be the right choice of promoter for the construct. Moreover, other researchers have also found that the actin promoter works well in driving gene 
expression (Dennis et al. 1984, McElroy et al. 1990, Christensen et al. 1992). Unlike the catalase-intron-containing GUS of pCAMBIA 1301, no intron was included in the modified Chondrus GUS construct given the clear preference of Chondrus for monoexonic genes which constitute $88 \%$ of all its genes (Collén et al. 2013).

It is known that success in transformation also largely depends on the right combination of factors such as the Agrobacterium strain, culture medium, tissue wounding, suppression and elimination of the bacterium post transformation (Opabode 2006). Subsequently, the transformation methodology used was tailored to foster optimal Chondrus-Agrobacterium interaction. The Agrobacterium LBA4404 strain was chosen because it is comparatively salt-tolerant. Furthermore, it has proved efficient in transforming plant species ranging from tobacco (Liang et al. 1997), rice and Arabidopsis (Kuriakose et al. 2009) to algae such as Chlamydomonas (Kumar et al. 2004), Chlorella vulgaris (Cha et al. 2012) and Schizochytrium (Cheng et al. 2012). Successful transient expression confirmed that Agrobacterium cells were viable in seawater (salinity 20) and could deliver T-DNA at this salinity at an even higher transformation efficiency (Figure 4). This could possibly be ascribed to the Chondrus cells being under less physiological stress than in induction medium (salinity 0.15) and better able to synthesize the GUS protein.

In Chondrus, as previously reported with Haematococcus pluvialis (Kathiresan et al. 2009), transformation occurred, unaided by acetosyringone, pointing to the possible release of a small amount of endogenous phenolic compounds from the wounded cells. Algal extracts are known to be rich in polyphenols particularly phlorotannins in brown algae (O'Sullivan et al. 2011, Stabili et al. 2012). It has been postulated that phenolics are specifically mobilized in Chondrus in response to pathogenic attack (Bouarab et al. 2004). However, the significantly higher transformation efficiency obtained with acetosyringone highlighted the importance of using phenolics in transforming Chondrus (Figure 4). A significantly higher transformation efficiency was reported in the presence of a phenolic compound (Kimura et al. 2015). However, the effects of phenolic compounds such as acetosyringone on transformation efficiency depend on the host types and bacterial strains (Ainsley et al. 2001, Wang et al. 2002).

While T-DNA transfer to unwounded cells was reported in the microalgae Haematococcus pluvialis (Kathiresan et al. 2009) and Chlamydomonas reinhardtii (Kumar et al. 2004), wounding was required with Chondrus (Figure 4). Agrobacterium has a Vir A/Vir G system which is finely tuned to respond to wound site signals (Pitzschke and Hirt 2010). According to Stachel et al. (1985), wounding not only favours the production of signal phenolics but also enhances accessibility of putative cell wall binding factors to the bacterium (Lippincott and Lippincott 1969). The tears, cuts and pinpricks might have also facilitated penetration of the bacteria into the tissue as evidenced by the blue inner medullary filaments (Figure 5). With biolistics, microparticles penetrate the cuticle layer and cell walls, creating numerous potential infection sites simultaneously. Although no visual damage was apparent, it was possible that this micro-wounding method compromised gene expression through cellular damage. A large amount of wounding could cause instant cell lysis while sublethal amounts could temporarily suppress RNA and protein synthesis, and moderate levels could induce cell wall rupture (Joersbo and Brunstedt 1992). On the other hand, insufficient puncture and wounding of cells would fail to attract Agrobacterium, possibly accounting for the absence of staining at some wound sites (Figure 4). This confirmed the importance of choosing a suitable wounding method for the organism to be transformed.

\section{Conclusion}

This study points to the amenability of Chondrus to be transformed by Agrobacterium in vitro. This study could serve as a stepping stone to facilitate further transgenic studies of Chondrus such as those aimed at deciphering the function of important Chondrus red algal genes involved in carrageenan metabolic pathways (Waaland et al. 2004). It would be worthwhile, for example, to enhance expression cassette elements, and test different virulent bacterial strains, other phenolic inducers or wounding methods. To obtain a more comprehensive insight into the superiority of the Chondrus-specific cassette, quantitative methods of gene expression such as quantitative real-time PCR would be useful. In particular, other methods or wounding strategies favouring more homogeneous penetration and infection of a larger area of thallus tissue by Agrobacterium e.g. vacuum infiltration, would further enhance the transformation protocol. Furthermore, the prior development of robust Chondrus regeneration and selection protocols from transformed cells is warranted in order to establish stable Agrobacterium-mediated transformation of Chondrus.

Acknowledgements: The authors would like to express their gratitude to the Agri-Food and Biosciences Institute (AFBI), Belfast, for the provision of their Biolistic machine and Scanning Electron Microscopy facility, and the University of Bristol for technical training. The project received 
funding from the Queen's University Belfast (QUB) and the University Malaya-QUB Research Collaboration on Biotechnological Applications of Selected Tropical and Temperate Seaweeds (UMQUB2A-2011).

\section{References}

Ainsley, P., G. Collins and M. Sedgley. 2001. Factors affecting Agrobacterium-mediated gene transfer and the selection of transgenic calli in paper shell almond (Prunus dulcis Mill.). J. Hortic. Sci. Biotechnol. 76: 522-528.

Ando, A., Y. Sumida, H. Negoro, D.A. Suroto, J. Ogawa, E. Sakuradani and S. Shimizu. 2009. Establishment of Agrobacterium tumefaciens-mediated transformation of an oleaginous fungus, Mortierella alpine 1S-4, and its application for eicosapentaenoic acid producer breeding. Appl. Environ. Microbiol. 75: 5529-5535.

Anila, N., A. Chandrashekar, G.A. Ravishankar and R. Sarada. 2011. Establishment of Agrobacterium tumefaciens-mediated genetic transformation in Dunaliella bardawil. Eur. J. Phycol. 46: 36-44.

Barahimipour, R., J. Neupert and R. Bock. 2016. Efficient expression of nuclear transgenes in the green alga Chlamydomonas: synthesis of an HIV antigen and development of a new selectable marker. Plant Mol. Biol. 90: 403-418.

Bhattacharya, A., P. Sood and V. Citovsky. 2010. The roles of plant phenolics in defence and communication during Agrobacterium and Rhizobium infection. Mol. Plant Pathol. 11: 750-719.

Bouarab, K., F. Adas, E. Gaquerel, B. Kloareg, J-P. Salaün and P. Potin. 2004. The innate immunity of a marine red alga involves oxylipins from both the eicosanoid and octadecanoid pathways. Plant Physiol. 135: 1838-1848.

Bourras, S., T. Rouxel and M. Meyer. 2015. Agrobacterium tumefaciens gene transfer: how a plant pathogen hacks the nuclei of plant and nonplant organisms. Phytopathology 105: 1288-1301.

Brawley, S.H., N.A. Blouin, E. Ficko-Blean, G.L. Wheeler, M. Lohr, H.V. Goodson, J.W. Jenkins, C.E. Blaby-Haas, K.E. Helliwell, C.X. Chan, T.N. Marriage, D. Bhattacharya, A.S. Klein, Y. Badis, J. Brodie, Y. Cao, J. Collén, S.M. Dittami, C.M.M. Gachon, B.R. Green, S.J. Karpowicz, J.W. Kim, U.J. Kudahl, S. Lin, G. Michel, M. Mittag, B.J.S. COlson, J.L. Pangilinan, Y. Peng, H. Qiu, S. Shu, J.T. Singer, A.G. Smith, B.N. Sprecher, V. Wagner, W. Wang, Z.Y. Wang, J. Yan, C. Yarish, S. Zäuner-Riek, Y. Zhuang, Y. Zou, E.A. Lindquist, J. Grimwood, K.W. Barry, D.S. Rokhsar, J. Schmutz, J.W. Stiller, A.R. Grossman and S.E. Prochnik. 2017. Insights into the red algae and eukaryotic evolution from the genome of Porphyra umbilicalis (Bangiophyceae, Rhodophyta). Proc. Natl. Acad. Sci. USA 114: E6361-E6370.

Bulgakov, V.P., K.V. Kiselev, K.V. Yakovlev, Y.N. Zhuravlev, A.A. Gontcharov and N.A. Odintsova. 2006. Agrobacteriummediated transformation of sea urchin embryos. Biotechnol. J. 1: 454-461.

Cha, T.S., C.F. Chen, W. Yee, A. Aziz and S.H. Loh. 2011. Cinnamic acid, coumarin and vanillin: alternative phenolic compounds for efficient Agrobacterium-mediated transformation of the unicellular green alga, Nannochloropsis sp. J. Microbiol. Methods 84: 430-434.
Cha, T.S., W. Yee and A. Aziz. 2012. Assessment of factors affecting Agrobacterium-mediated genetic transformation of the unicellular green alga, Chlorella vulgaris. World J. Microbiol. Biotechnol. 28: 1771-1779.

Cheney, D., B. Metz and J. Stiller. 2001. Agrobacterium-mediated genetic transformation in the macroscopic marine red alga Porphyra yezoensis. J. Phycol. 37: 11.

Cheng, R., R. Ma, K. Li, H. Rong, X. Lin, Z. Wang, S. Yang and Y. Ma. 2012. Agrobacterium tumefaciens mediated transformation of marine microalgae Schizochytrium. Microbiol. Res. 167: 179-186.

Christensen, A.H., R.A. Sharrock and P.H. Quail. 1992. Maize polyubiquitin genes: structure, thermal perturbation of expression and transcript splicing, and promoter activity following transfer to protoplasts by electroporation. Plant Mol. Biol. 18: 675-689.

Collén, J., W. Carré, S.G. Ball, C. Chaparro, T. Tonon, T. Barbeyron, G. Michel, B. Noel, K. Valentin, M. Elias, F. Artiguenave, A. Arun, J.M. Aury, J.F. Barbosa-Neto, J.H. Bothwell, F.Y. Bouget, L. Brillet, F. Cabello-Hurtado, S. Capella-Gutiérrez, B. Charrier, L. Cladière, J.M. Cock, S.M. Coelho, C. Colleoni, M. Czjzek, C. Da Silva, L. Delage, F. Denoeud, P. Deschamps, S.M. Dittami, T. Gabaldón, C.M. Gachon, A. Groisillier, C. Hervé, K. Jabbari, M. Katinka, B. Kloareg, N. Kowalczyk, K. Labadie, C. Leblanc, P.J. Lopez, D.H. McLachlan, L. Meslet-Cladiere, A. Moustafa, Z. Nehr, P. Nyvall Collén, O. Panaud, F. Partensky, J. Poulain, S.A. Rensing, S. Rousvoal, G. Samson, A. Symeonidi, J. Weissenbach, A. Zambounis, P. Wincker and C. Boyen. 2013. Genome structure and metabolic features in the red seaweed Chondrus crispus shed light on evolution of the Archaeplastida. Proc. Natl. Acad. Sci. USA 110: 5247-5252.

Dennis, E.S., W.L. Gerlach, A.J. Pryor, J.L. Bennetzen, A. Inglis, D. Llewellyn, M.M. Sachs, R.J. Ferl and W.J. Peacock. 1984. Molecular analysis of the alcohol dehydrogenase (Adh1) gene of maize. Nucleic Acids Res. 12: 3983-4000.

Duan, H.Y., X.S. Ding, J.Y. Song, Y.L. He and Y.Q. Zhou. 2013. Plant regeneration and Agrobacterium-mediated transformation of Achyranthes bidentata using cotton EREBP gene. Braz. Arch. Biol. Technol. 56: 349-356.

Fukuda, S., K. Mikami, T. Uji, E.J. Park, T. Ohba, K. Asada, Y. Kitade, H. Endo, I. Kato and N. Saga. 2008. Factors influencing efficiency of transient gene expression in the red macrophyte Porphyra yezoensis. Plant Sci. 174: 329-339.

Gan, S.Y. and C.A. Maggs. 2017. Random mutagenesis and precise gene editing technologies: applications in algal crop improvement and functional genomics. Eur. J. Phycol. 52: 466-481.

Gan, S.Y., S. Qin, R.Y. Othman, D. Yu and S.M. Phang. 2003. Transient expression of lacZ in particle bombarded Gracilaria changii (Gracilariales, Rhodophyta). J. Appl. Phycol. 15: 345-349.

Gan, S.Y., R.Y. Othman and S.M. Phang. 2005. Agrobacteriummediated transformation of Gracilaria changii (Gracilariales, Rhodophyta), a tropical red alga. Phycologia 44: 35.

Gelvin, S.B. 2003. Agrobacterium-mediated plant transformation: the biology behind the "gene-jockeying" tool. Microbiol. Mol. Biol. Rev. 67: 16-37.

Gelvin, S.B. 2006. Agrobacterium virulence gene induction. Methods Mol. Biol. 343: 77-84.

Guiry, M.D. and E.M. Cunningham. 1984. Photoperiodic and temperature responses in the reproduction of north-eastern Atlantic Gigartina acicularis (Rhodophyta: Gigartinales). Phycologia 23: 357-367. 
Guiseley, K.B. 1989. Chemical and physical properties of algal polysaccharides used for cell immobilization. Enzyme Microbial Technol. 11: 706-716.

Gustafsson, C., S. Govindarajan and J. Minshull. 2004. Codon bias and heterologous protein expression. Trends Biotechnol. 22: 346-353.

Handayani, T., A. Alimuddin, U. Widyastuti, E. Suryati and A. Parenrengi. 2014. Binary vector construction and Agrobacterium tumefaciens-mediated transformation of lysozyme gene in seaweed Kappaphycus alvarezii. Biotropia 21: 80-90.

Heindl, J.E., Y. Wang, B.C. Heckel, B. Mohari, N. Feirer and C. Fuqua. 2014. Mechanisms and regulation of surface interactions and biofilm formation in Agrobacterium. Front. Plant Sci. 5: 176.

Hirata, R., T. Uji, S. Fukuda, H. Mizuta, A. Fujiyama, S. Tabata and N. Saga. 2014. Development of a nuclear transformation system with a codon-optimized selection marker and reporter genes in Pyropia yezoensis (Rhodophyta). J. Appl. Phycol. 26: 1863-1868.

Holdt, S.L. and S. Kraan. 2011. Bioactive compounds in seaweed: functional food applications and legislation. J. Appl. Phycol. 23: 543-597.

Huddy, S.M., A.E. Meyers and V.E. Coyne. 2012. Transformation of lacZ using different promoters in the commercially important red alga, Gracilaria gracilis. Afr. J. Biotechnol. 11: 1879-1885.

Hwang, H.-H., S.B. Gelvin and E.-M. Lai. 2015. Editorial: Agrobacterium biology and its application to transgenic plant production. Front. Plant Sci. 6: 265.

Hwang, H.-H., M. Yu and E.-M. Lai. 2017. Agrobacterium-mediated plant transformation: biology and applications. Arabidopsis Book 15: e0186.

Joersbo, M. and J. Brunstedt. 1992. Sonication: a new method for gene transfer to plants. Physiol. Plant. 85: 230-234.

Kathiresan, S., A. Chandrashekar, G.A. Ravishankar and R. Sarada. 2009. Agrobacterium-mediated transformation in the green alga Haematococcus pluvialis (Chlorophyceae, Volvocales). J. Phycol. 45: 642-649.

Kimura, M., S. Cutler and S. Isobe. 2015. A novel phenolic compound, chloroxynil, improves Agrobacterium-mediated transient transformation in Lotus japonicus. PLoS One 10: e0131626.

Kraan, S. 2012. Algal polysaccharides, novel applications and outlook. In: (C.F. Chang, ed.) Carbohydrates - Comprehensive studies on glycobiology and glycotechnology. InTech Open. pp. 489-532.

Kuang, M., S.J. Wang, Y. Li, D.L. Shen and C.K. Zeng. 1998. Transient expression of exogenous gus gene in Porphyra yezoensis (Rhodophyta). Chin. J. Ocean. Limnol. 16: 56-61.

Kübler, J.E., S.C. Minocha and A.C. Mathieson. 1994. Transient expression of the GUS reporter gene in protoplasts of Porphyra miniata (Rhodophyta). J. Mar. Biotechnol. 1: 165-169.

Kucho, K.I., K. Kakoi, M. Yamaura, M. Iwashita, M. Abe and T. Uchiumi. 2013. Codon-optimized antibiotic resistance gene improves efficiency of transient transformation in Frankia. J. Biosci. 38: 713-717.

Kumar, S.V., R.W. Misquitta, V.S. Reddy, B.J. Rao and M.V. Rajam. 2004. Genetic transformation of the green alga Chlamydomonas reinhardtii by Agrobacterium tumefaciens. Plant Sci. 166: 731-738.

Kunik, T., T. Tzfira, Y. Kapulnik, Y. Gafni, C. Dingwall and V. Citovsky. 2001. Genetic transformation of HeLa cells by Agrobacterium. Proc. Natl. Acad. Sci. USA 98: 1871-1876.
Kuriakose, B., V. Arun, S.S. Gnanamanickam and G. Thomas. 2009. Tissue-specific expression in transgenic rice and Arabidopsis thaliana plants of GUS gene driven by the 5 ' regulatory sequences of an anther specific rice gene YY2. Plant Sci. 177: 390-397.

Kurtzman, A.M. and D.P. Cheney. 1991. Direct gene transfer and transient expression in a marine red alga using the biolistic method. J. Phycol. 27: 42.

Lacroix, B. and V. Citovsky. 2013. The roles of bacterial and host plant factors in Agrobacterium-mediated genetic transformation. Int. J. Dev. Biol. 57: 467-481.

Lapidot, M., D. Raveh, A. Sivan, S.M. Arad and M. Shapira. 2002. Stable chloroplast transformation of the unicellular red alga Porphyridium species. Plant Physiol. 129: 7-12.

Liang, Z., D. Ma, L. Tang, Y. Hong, A. Luo, J. Zhou and X. Dai. 1997. Expression of the spinach betaine aldehyde dehydrogenase (BADH) gene in transgenic tobacco plants. Chin. J. Biotechnol. 13: 153-159.

Lin, C., C. Yarish and T. Chen. 2004. Development of a novel gene transfer method in Porphyra. Bull. Fish. Res. Agen. Supplement 1: 155.

Lin, X., S. Liu, R. Bao, N. Gao, S. Zhang, R. Zhu and Z.K. Zhao. 2017. Development of an Agrobacterium-mediated transformation method and evaluation of two exogenous constitutive promoters in oleaginous yeast Lipomyces starkeyi. Appl. Biochem. Biotechnol. 183: 867.

Lippincott, B.B. and J.A. Lippincott. 1969. Bacterial attachment to a specific wound site as an essential stage in tumor initiation by Agrobacterium tumefaciens. J. Bacteriol. 97: 620-628.

Maggs, C.A., H. Verbruggen and O. De Clerck. 2008. Molecular systematics of red algae: building future structures on firm foundations. In: (J. Brodie and J. Lewis, eds) Unravelling the algae. Taylor and Francis, Abingdon. pp. 103-121.

Mathias, R.J. and L.A. Boyd. 1986. Cefotaxime stimulates callus growth, embryogenesis and regeneration in hexaploid bread wheat (Triticum aestivum L EM Thell). Plant Sci. 46: 217-223.

Matthysse, A.G. and V.T. Wagner. 1994. Attachment of Agrobacterium tumefaciens to host cells. In: (C.I. Kado and J.H. Crosa, eds) Molecular mechanisms of bacterial virulence. Developments in plant pathology vol. 3. Springer, Dordrecht. pp. 79-92.

McElroy, D., W. Zhang, J. Cao and R. Wu. 1990. Isolation of an efficient actin promoter for use in rice transformation. Plant Cell 2: 163-171.

Mikami, K., T. Uji, L. Li, M. Takahashi, H. Yasui and N. Saga. 2009. Visualization of phosphoinositides via the development of the transient expression system of a cyan fluorescent protein in the red alga Porphyra yezoensis. Mar. Biotechnol. 11: 563-569.

Minoda, A., R. Sakagami, F. Yagisawa, T. Kuroiwa and K. Tanaka. 2004. Improvement of culture conditions and evidence for nuclear transformation by homologous recombination in a red alga, Cyanidioschyzon merolae 10D. Plant Cell Physiol. 45: 667-671.

Mizukami, Y., M. Hado, H. Kito, M. Kunimoto and N. Murase. 2004. Reporter gene introduction and transient expression in protoplasts of Porphyra yezoensis. J. Appl. Phycol. 16: 23-29.

Necas, J. and L. Bartosikova. 2013. Carrageenan: a review. Veterinarni Medicina 58: 187-205.

Opabode, J.T. 2006. Agrobacterium-mediated transformation of plants: emerging factors that influence efficiency. Biotechnol. Mol. Bio. Rev. 1: 12-20. 
O'Sullivan, A.M., Y.C. O'Callaghan, M.N. O'Grady, B. Queguineur, D. Hanniffy, D.J. Troy, J.P. Kerry and N.M. O’Brien. 2011. In vitro and cellular antioxidant activities of seaweed extracts prepared from five brown seaweeds harvested in spring from the west coast of Ireland. Food Chem. 126: 1064-1070.

Pitzschke, A. and H. Hirt. 2010. New insights into an old story: Agrobacterium-induced tumour formation in plants by plant transformation. EMBO J. 29: 1021-1032.

Pratheesh, P.T., M. Vineetha and G.M. Kurup. 2014. An efficient protocol for the Agrobacterium-mediated genetic transformation of microalga Chlamydomonas reinhardtii. Mol. Biotechnol. 56: 507-515.

Rolloos, M., P.J.J. Hooykaas and B.J. van der Zaal. 2015. Enhanced targeted integration mediated by translocated I-Scel during the Agrobacterium mediated transformation of yeast. Sci. Rep. 5: 8345.

Seagull, R.W. 1989. The plant cytoskeleton. CRC Crit. Rev. Plant Sci. 8: 131-167.

Simoh, S., H.J.M. Linthorst and R. Verpoorte. 2007. Host-bacterium interactions in Agrobacterium tumefaciens-mediated plant transformation: mechanism of action and Agrobacterium/plant factors involved. Curr. Topics Plant Biol. 8: 1-20.

Šnajder, M., M. Mihelič, D. Turk and N.P. Ulrih. 2015. Codon optimisation is key for pernisine expression in Escherichia coli. PLoS One 10: e0123288.

Son, S.H., J.W. Ahn, T. Uji, D.W. Choi, E.J. Park, M.S. Hwang, J.R. Liu, D. Choi, K. Mikami and W.J. Jeong. 2011. Development of an expression system using the heat shock protein 70 promoter in the red macroalga, Porphyra tenera. J. Appl. Phycol. 24: 79-87.

Srinivasan, R. and K.M. Gothandam. 2016. Synergistic action of D-glucose and acetosyringone on Agrobacterium strains for efficient Dunaliella transformation. PLoS One 11: e0158322.

Stabili, L., M.I. Acquaviva, F. Biandolino, R.A. Cavallo, S.A. De Pascali, F.P. Fanizzi, M. Narracci, A. Petrocelli and E. Cecere. 2012. The lipidic extract of the seaweed Gracilariopsis longissima (Rhodophyta, Gracilariales): a potential resource for biotechnological purposes? New Biotechnol. 29: 443-450.

Stachel, S.E., E. Messens, M. Van Montagu and P.C. Zambryski. 1985. Identification of the signal molecules produced by wounded plant cell that activate T-DNA transfer in Agrobacterium tumefaciens. Nature 318: 624-629.

Subramoni, S., N. Nathoo, E. Klimov and Z.-C. Yuan. 2014. Agrobacterium tumefaciens responses to plant-derived signaling molecules. Front. Plant Sci. 5: 322.

Takahashi, M., T. Uji, N. Saga and K. Mikami. 2010. Isolation and regeneration of transiently transformed protoplasts from gametophytic blades of the marine red alga Porphyra yezoensis. Electronic J. Biotech. 13: 7.

Triana, S.H., A. Alimuddin, U. Widyastuti, Suharsono, E. Suryati and A. Parenrengi. 2016. The method of Agrobacterium tumefaciens-mediated $\mathrm{MmCu} / \mathrm{Zn}-\mathrm{SOD}$ gene transformation in the red seaweed Kappaphycus alvarezii. Pak. J. Biotechnol. 13: 221-230.

Tzfira, T. and V. Citovsky. 2002. Partners-in-infection: host proteins involved in the transformation of plant cells by Agrobacterium. Trends Cell Biol. 12: 121-129.

Tzfira, T. and V. Citovsky. 2006. Agrobacterium-mediated genetic transformation of plants: biology and biotechnology. Curr. Opin. Biotechnol. 17: 147-154.
Verbruggen, H., C.A. Maggs, G.W. Saunders, L.L. Gall, H.S. Yoon and O.D. Clerck. 2010. Data mining approach identifies research priorities and data requirements for resolving the red algal tree of life. BMC Evol. Biol. 10: 1-15.

Waaland, J.R., J.W. Stiller and D.P. Cheney. 2004. Macroalgal candidates for genomics. J. Phycol. 40: 26-33.

Wang, Y.Q., X.G. Xiao and A.M. Zhang. 2002. Factors affecting Agrobacterium tumefaciens-mediated transformation of wheat (Triticum aestivum L.). Yi Chuan Xue Bao 29: 260-265.

Wang, J., P. Jiang, Y. Cui, X. Guan and S. Qin. 2010. Gene transfer into conchospores of Porphyra haitanensis (Bangiales, Rhodophyta) by glass bead agitation. Phycologia 49: 355-360.

Wise, A.A., Z. Liu and A.N. Binns. 2006. Three methods for the introduction of foreign DNA into Agrobacterium. Methods Mol. Biol. 343: 43-53.

Yoon, H.S., J.D. Hackett, C. Ciniglia, G. Pinto and D. Bhattacharya. 2004. A molecular timeline for the origin of photosynthetic eukaryotes. Mol. Biol. Evol. 21: 809-818.

Zhang, J.J., L. Shi, H. Chen, Y.Q. Sun, M.W. Zhao, A. Ren, M.J. Chen, H. Wang and Z.Y. Feng. 2014. An efficient Agrobacteriummediated transformation method for the edible mushroom Hypsizygus marmoreus. Microbiol. Res. 169: 741-748.

Zheng, Z., C. Huang, L. Cao, C. Xie and R. Han. 2011. Agrobacterium tumefaciens-mediated transformation as a tool for insertional mutagenesis in medicinal fungus Cordyceps militaris. Fungal Biol. 115: 265-274.

Zhou, Z., Y. Dang, M. Zhou, L. Li, C. Yu, J. Fu, S. Chen and Y. Liu. 2016. Codon usage is an important determinant of gene expression levels largely through its effects on transcription. Proc. Natl. Acad. Sci. USA 113: 6117-6125.

Zupan, J., T.R. Muth, O. Draper and P. Zambryski. 2000. The transfer of DNA from Agrobacterium tumefaciens into plants: a feast of fundamental insights. Plant J. 23: 11-28.

Supplementary Material: The online version of this article offers supplementary material (https://doi.org/10.1515/bot-2018-0028).

\section{Bionotes}

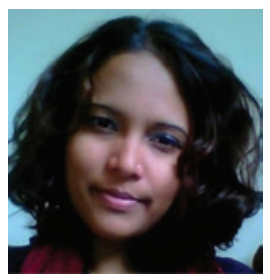

Anusha Devi Ramessur

School of Biological Sciences, Medical Biology Centre, Queen's University Belfast, Belfast, Northern Ireland

Anusha Devi Ramessur joined Queen's University Belfast following her MSc degree in Biotechnology at Aston University. Her PhD, Genetic transformation of red macroalgae - novel techniques in commercially and scientifically important species, was carried out jointly between QUB and the University of Malaya and awarded in 2013. Anusha is now working in biotechnology. 


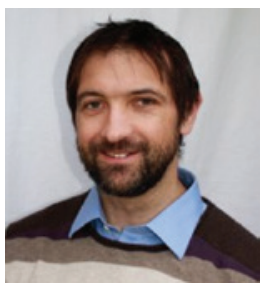

John H. Bothwell

School of Biological Sciences, Medical Biology Centre, Queen's University Belfast, Belfast, Northern Ireland; and School of Biological and Biomedical Sciences, Durham University, South Road, Durham, England

John H. Bothwell works on seaweed, primarily on their evolution and genomics. His interests also include their bioenergy potential and their ecological importance along the UK's coastlines. He was awarded DPhil in Biochemistry in 2000 at Oxford and has held postdoctoral research fellowships in Cambridge, Plymouth and Roscoff. Previously, he held a lectureship at Queen's University Belfast and currently is in the Department of Biosciences, Durham University.

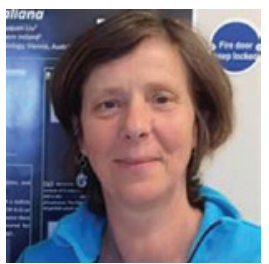

\section{Christine A. Maggs}

School of Biological Sciences, Portaferry Marine Laboratory, Queen's University Belfast, Northern Ireland

Christine A. Maggs worked for three decades in Queen's University Belfast. She held the positions of Lecturer, Reader, Professor of Phycology and Director of Research before taking on the role of Head of School of Biological Sciences. She moved to Bournemouth University in 2015, and is now Chief Scientist and Deputy CEO of JNCC. She has served on the UK's Research Excellence Framework subpanel UoA7 in REF2014 and REF2021, is a member of the Royal Irish Academy, and has an award of Excellence from the Phycological Society of America.

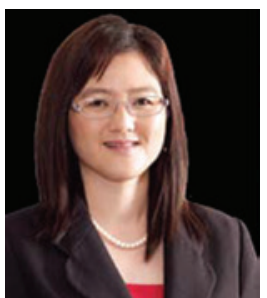

Sook Yee Gan

Department of Life Sciences, School of Pharmacy, International Medical University, No. 126, Jalan Jalil Perkasa 19, Bukit Jalil, 57000 Kuala Lumpur, Malaysia

Sook Yee Gan obtained her PhD from the University of Malaya in the area of Algal Genetic transformation. Presently, she is attached as a senior lecturer in the Department of Life Sciences, School of Pharmacy, International Medical University, Malaysia. Her research interests include the use of molecular tools in understanding diseases such as cancer and Alzheimer's disease as well as natural product research, in particular the protective mechanisms of active compounds in neurodegenerative diseases and type-II diabetes.

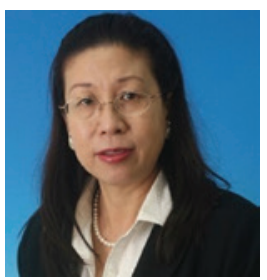

Siew Moi Phang

Institute of Ocean and Earth Sciences, University of Malaya, 50603 Kuala Lumpur, Malaysia, phang@um.edu.my

Siew-Moi Phang obtained her PhD from the University of Malaya, Malaysia, in Applied Phycology. She pioneered algal biotechnology research in Malaysia, and established the Algal Research Laboratory in the University of Malaya. She served as the Director of the Institute of Ocean and Earth Sciences (IOES), University of Malaya from 2007 until 2018. She is a Fellow of the Academy of Sciences Malaysia and the Marine Biological Association, United Kingdom. She also serves as assistant editor, Journal of Applied Phycology. 